\title{
The Implementation of the Movement for Strengthening Character Education in Primary Schools Through Lombok Traditional Games at SDN 44 Mataram
}

\author{
Ilham Syahrul Jiwandono* \\ Primary School Education Program \\ Universitas Mataram \\ Mataram Indonesia \\ ilham_jiwandono@unram.ac.id
}

\author{
Mansur Hakim \\ Primary School Education Program \\ Universitas Mataram \\ Mataram Indonesia
}

\author{
Khairun Nisa \\ Primary School Education Program \\ Universitas Mataram \\ Mataram Indonesia
}

\author{
Awal Nur Kholifatur Rosyidah \\ Primary School Education Program \\ Universitas Mataram \\ Mataram Indonesia
}

\author{
Nasaruddin Nasaruddin \\ Primary School Education Program \\ Universitas Mataram \\ Mataram Indonesia
}

\begin{abstract}
The $21^{\text {st }}$ century learning process is not only based on the use of the textbook as the source, but it also can be referred to the use of other sources, such as traditional games. In the traditional games, there are many character values that the students can learn. It is in line with the government program dealing with the Character Education Strengthening (CES). This study aims at determining the implementation of the $\mathrm{CE}$ movement in building the students' character. This research used qualitative descriptive approach. The study was conducted at SDN 44 Mataram. Data were collected by using interviews, observation and documentation. Phases of data analysis include reduction, presentation and conclusion. The results of study show that: (1) The use of traditional games was very helpful for teachers in building students' characters because there are many values contained in the game such as discipline and responsibility. (2) Students gain new experiences because the learning process does not only focus on student textbooks. (3) The students were delighted and enthusiastic in doing traditional games because they gain a new learning atmosphere. (4) There were changes in attitudes of the students after doing the traditional game, especially in discipline and responsibility.
\end{abstract}

Keywords - character education strengthening, characters, traditional games

\section{INTRODUCTION}

The Indonesian independence has been more than 74 years, but there have not been many good changes or better improvement which can meet the hope of Indonesian people. This may be caused by the moral deterioration of the majority of citizens and the civil service. In addition, our education system still provided and promoted more portions on the cognitive aspect than the affective aspect. For these issues, the government finally issued the movement to strengthen the character education.
This movement is mainly to restore the character education as the spirit of national education through hearted exercise, sensitiveness exercise, physical exercise, and reasoning exercise. There are five main values developed in the CES movement, namely religious, nationalist, independent, mutual cooperation and integrity. This movement is seen as one of the important things in restoring the declining character of the nation. Character education is the education system intended to form the character through the process of knowing the good, loving the good and acting the good.

One of the approaches used in learning the character is a learning-by-doing approach. This approach emphasizes on efforts to provide opportunities for students to do moral actions. One of practice skills that can be used is the traditional game which is familiar to the students and in this case the traditional game used is from Sasak, Lombok. It is acknowledged that the traditional games have or contain many character values which modern games do not have. These values include honesty, mutual cooperation, discipline, respect and tolerance to others. These traditional games provide reinforcement for interpersonal relationship which can encourage people to take care to others such as: mutual attention, tolerance, friendship and discipline. In addition, through traditional games, students will learn to appreciate one another as creatures of God.

It is acknowledged that the traditional games lack in use for the purpose of learning in the classroom as a way to strengthen the child's character. Thus, it is necessary that teachers begun to utilize traditional games optimally in the process of teaching and learning in the classrom. 


\section{RESEARCH METHOD}

This research used qualitative research methods Qualitative research method is defined as research procedure that can produce descriptive data in the form of written and oral about the research subjects that have been observed. Moleong [1] explains that qualitative research is research that aims to understand phenomena or behavior experienced by research subjects which then described in the form of words. The stages applied in this research are: (1) pre-field, (2) field work and (3) data analysis. The research location was at primary school (SDN) 44 Mataram. The data were collected from primary and secondary sources. The primary data sources are principal, teachers and students. While, the secondary data sources are documentation and field notes. The data were collected by using interviews, observation and documentation. Further, the collected data were analyzed by using data analysis techniques of Miles and Huberman, including data reduction, data presentation, and conclusion or verification [2].

\section{RESULTS AND DISCUSSION}

\section{A. The Indonesians' Character and the Urgency of Character Education for the Indonesians}

Education is the process of internalizing values to individuals through the learning process. Character education is the main foundation for the development of Indonesia. There are several indicators that show the degradation of the characters currently happened in Indonesia. The First is the lack of respect for the teacher. This is proved by the many disputes between teachers and students or with parents. Currently, the teaching profession is sometimes seen as a dishonor profession. Many students did not hesitate to mock their teacher even to hit him/her. The Second is the high number of delinquency committed by students. This is proved by the high incidence of crimes committed by students, such as drugs, brawling and freesex. The third is the high number of corruption committed by citizens and civil servants. Corruption has bad impacts on the nation institutionally and in relations between citizens. In terms of the institutional aspects, it will impact aspects for national development to be not effective, such as the construction of houses after the earthquake in Lombok in which the house building quality is bad. In terms of interpersonal relations, corruption may cause horizontal conflicts among citizens. Based on these cases, it can be inferred that the current process of teaching and learning in the classroom only emphasizes cognitive aspects, while ignoring affective aspects.

The formation of student character should not only be put or embedded on the subjects of citizenship and religious education, but also on other subjects, such as biology. Lepiyanto [3] states that there are some character values that can be obtained by students through biology subjects including caring, independent, religious, friendly and communicative. The teacher's role is very important on forming student character. The results of research conducted by Lepiyanto show that playing a role in the material of human organs can enhance the character of cooperation, courage and confidence. Based on the preliminary study at SD 44 Mataram, it was found that some students did not respect the teachers. The result of observation shows that many students behave badly to their teachers and also to their friends, such as saying impolite words, not doing the teacher's orders, and bullying other students.

In the teaching and learning process, teachers can have double roles. First, the teacher becomes a role model for the students. Second, the teacher can control and lead the behavior of the students to be appropriate with good character expected. To develop the character in students, it is necessary to pay attention to the material to be taught and the types of learning activity as the nurturant effect on the learning process performed by the students.

In realizing character education, teachers are required to be able to teach the values of character well and then get students used to implement the character values. It is important to help students recognize the character values cognitively, then comprehend the values affectively and practice them in their daily lives. Based on the statement above, the contents of character education should be integrated into all subjects in the school, not only in the subjects of citizenship and religious education. Based on the interviews with the principal of SD 44 Mataram, it was found that all the components in the school had tried to maximally develop the student character, but the expected results were still not achieved.

The Movement for Strengthening Character Education (MSCE) has a very important role as the government issued a mental revolution. MSCE is considered as one of the ways to make the mental revolution succeed. Therefore, MSCE puts the spirit of character education in national education as the deepest dimension in the world of education. There are five values developed in the MSCE program, namely religious, nationalist, independent, mutual cooperation, integrity [4]. According to Ki Hajar Dewantara, there are four philosophies for the development of character values, namely the philosophy of the hearted exercise, reasoning exercise, sensitiveness exercise, and physical exercise.

These characters will be easily developed if they are commonly practiced. The interviews with teachers reveal that there are two strategies that have been used to teach the character of responsibility in children. First is by giving trust to children so that children are responsible for their actions. This is in accordance with Muslich [5] who states that if we believe in students being able to keep the commitments, then students will be personally responsible. Second is by avoiding giving gifts to students for the achievement they have got or good deeds they have done because this may create bad impact on students' attitudes in which they will always expect for the gifts for the achievement or good deeds they have done. However, instead of giving gifts, the teachers should praise the students for their achievement or good deeds they have done, i.e. by stating "good job," "well done," etc.

\section{B. Traditional Lombok Games as a Way to Implement the Movement of Strengthening Character Education}

Playing is a way of learning that cannot be separated from children [6]. Widodo [7] said that playing is an 
obligatory activity that children need to do to gain knowledge from their environment. The revolution of technological development has influenced the change in the play of children, for example in the past children often played traditional games but now they spend more time with gadgets. It should be acknowledged that traditional games have more character values than modern games. The traditional game is an entertaining activity using simple tools and it does not require complicated tool to play [8]. Traditional game is a very simple game, but it has extraordinary benefits [9]. This is in line with what the principal said, in which through traditional games the students gain extraordinary benefits, especially in the formation of character.

Saputra [10] said that traditional games have more benefits than modern games as it can stimulate children in creating characters, one of them is cooperation. Based on the results of the interview, the principal of SDN 44 Mataram stated that the current problem is more students spending their time in playing modern games instead of playing traditional games. It is because the parents give their children playing with smartphones, while ignoring to introduce the traditional games that have been played by their parents [11]. In fact, traditional games can develop many aspects, including aspects of motoric, social, cognitive and language [12]. Interviews with teachers show that traditional games have a lot of character values that can be developed, such as honesty, discipline, responsibility, tolerance, respect each other, and religious. Religious characters can be seen when children are able to like their environment and are friendly with their friends [10], [13].

The traditional games that can be used are those which are familiar and close to the environment and the lives of students. The results of Putri's research [14] showed that traditional games can create social characters in children. Based on observations, it is found that traditional games that are often used by students in the learning process are Begasingan and Lengkak Talik. These traditional games are familiar to the students and they are among the favorite games for students in Lombok. In Begasingan and Lengkak Talik games, a lot of character values are suitable for forming the student characters. Here are the values of character in these both games:

TABLE I. THE CHARACTERS IN THE GAME OF BEGASINGAN AND LENGKAK TALIK

\begin{tabular}{|c|c|}
\hline Games & Characters \\
\hline Begasingan & $\begin{array}{c}\text { Discipline, responsibility, respect, } \\
\text { honesty. }\end{array}$ \\
\hline Lengkak Talik & $\begin{array}{c}\text { Tolerance, discipline, cooperation, } \\
\text { helping others, creative, social } \\
\text { interaction. }\end{array}$ \\
\hline
\end{tabular}

Based on the table above, it can be concluded that the games of Begasingan and Lengkak Talik have lot of character values. The results of interviews with students show that they were very happy and excited playing with traditional games because they could interact and working together directly with other students. These values cannot be obtained in modern games that rely more on individualism. The results of research from Ekawati stated that traditional games can also improve children's intrapersonal abilities. This statement is in line with the opinion of Irman [15] in his article which said that traditional games emphasize the values of social characters rather than individual characters. Through the games, students gain experience that is beneficial for the their growth and development [16]. Thus, traditional games provide positive effects for students in developing their characters as it can be seen from the excitement of students and teachers when playing traditional games.

\section{CONCLUSION}

Based on the findings and discussion above, some conclusions be drawn as follows:

1. It can be said that the character of Indonesian people is being degraded. This can be seen from the indicators showing that many citizens and civil servants are involved in various criminal cases. Thus, this encouraged the government to issue the program for Strengthening Character Education for students.

2. There are four philosophies in character education, namely the hearted exercise, reasoning exercise, sensitiveness exercise, and physical exercise. The results of the study show that there are two strategies employed by teachers in developing character values for children, i.e.: giving confidence to children and avoiding giving the gifts to students for the achievement they have got or good deeds they have done. In addition, there are five approaches in forming the character of students, namely the value analysis approach, values clarification, learning by doing, moral development and values cultivation.

3. One of the ways to develop the value of the students' character is by employing or benefitting the traditional game. Begasingan and Lengkak Talik can be used because these games are familiar to the environment and the lives of students, and also they are among the favorite games for students in Lombok. In these games, there are many character values can be found including the cooperation and discipline values.

\section{REFERENCES}

[1] L. J. Moleong, Metode Penelitian Kualitatif. Bandung: PT. Remaja Rosdakarya, 2018.

[2] U. Husaini, Metodologi Penelitiam Sosial. Jakarta: Bumi Aksara, 2009

[3] A. Lepiyanto, "Membangun karakter siswa dalam pembelajaran biologi," Bioedukasi, vol. 2, no. 1, 2011.

[4] Kemendikbud, Konsep dan Pedoman Penguatan Pendidikan Karakter. Jakarta: Kemendikbud, 2017.

[5] M. Muslich, Pendidikan Karakter: Menjawab Tantangan Krisis Multidimensional. Jakarta: Bumi Aksara, 2011.

[6] R. Wijayanti, "Permainan Tradisional Sebagai Media Pengembangan Kemampuan Sosial Anak," J. CARE (Children Advis. Res. Educ., vol. 4, no. 1, pp. 69-79, 2016.

[7] P. Widodo and R. Lumintuarso, "Pengembangan model permainan tradisional untuk membangun karakter pada siswa SD kelas atas," J. Keolahragaan, vol. 5, no. 2, pp. 183-193, 2017.

[8] N. Siregar and W. Lestari, "Peranan permainan tradisional dalam mengembangkan kemampuan matematika anak usia sekolah dasar," J. Mercumatika J. Penelit. Mat. dan Pendidik. Mat., vol. 2, no. 2, pp. 1-7, 2018.

[9] I. Nurhayati, "Peran Permainan Tradisional Dalam Pembelajaran 
Anak Usia Dini (Studi di PAUD Geger Sunten, Desa Suntenjaya)," Empower. J. Ilm. Progr. Stud. Pendidik. Luar Sekol., vol. 1, no. 2, pp. 39-48, 2012.

[10] N. E. Saputra and Y. N. Ekawati, "Permainan tradisional sebagai upaya meningkatkan kemampuan dasar anak," J. Psikol. Jambi, vol. 2 , no. 2, pp. 47-53, 2017.

[11] H. Nur, "Membangun karakter anak melalui permainan anak tradisional," J. Pendidik. Karakter, no. 1, 2013.

[12] I. Khasanah, A. Prasetyo, and E. Rakhmawati, "Permainan tradisional sebagai media stimulasi aspek perkembangan anak usia dini," PAUDIA J. Penelit. dalam Bid. Pendidik. Anak Usia Dini, vol. 1 , no. $1,2011$.

[13] S. Y. Saputra, "Permainan tradisional vs permainan modern dalam penanaman nilai karakter di sekolah dasar," ELSE (Elementary Sch. Educ. Journal) J. Pendidik. dan Pembelajaran Sekol. Dasar, vol. 1, no. 1, 2017

[14] A. R. Nourovita, "Efektivitas Permainan Tradisional Jawa dalam Meningkatkan Penyesuaian Sosial pada Anak Usia 4-5 tahun di Kecamatan Suruh," BELIA Early Child. Educ. Pap., vol. 2, no. 1, 2013.

[15] I. Irman, "Nilai-Nilai Karakter pada Anak Dalam Permainan Tradisionan dan Moderen," KONSELI J. Bimbing. dan Konseling, vol. 4, no. 2, pp. 89-96, 2017.

[16] G. M. Anggita, "Eksistensi Permainan Tradisional sebagai Warisan Budaya Bangsa," JOSSAE J. Sport Sci. Educ., vol. 3, no. 2, pp. 5559, 2019. 